\title{
PARTISIPASI PEDAGANG KAKI LIMA \\ DALAM PENGELOLAAN KEBERSIHAN LINGKUNGAN \\ DI KOTA SOLOK \\ ( Studi kasus di Beberapa Ruas Jalan Utama Kota Solok ) \\ Dido Nurheri ${ }^{1}$, Paus Iskarni ${ }^{2}$, Hendry Frananda ${ }^{2}$ \\ Program Studi Geografi \\ Fakultas Ilmu Sosial, Universitas Negeri Padang \\ Email: nurherrydido@gmail.com
}

\begin{abstract}
ABSTRAK
Penelitian ini bertujuan untuk mengetahui bentuk dan tingkat partisipasi pedagang kaki lima dan upaya pemerintah dalam mengoptimalkan partisipasi pedagang kaki lima dalam pengelolaan kebersihan lingkungan. Metode penelitian yang digunakan dalam penulisan Skripsi adalah metode diskriptif Kualitatif, akan tetapi tidak kualitatif murni. Hasil penelitian menunjukkan ada empat bentuk partipasi pedagang kaki lima beserta tingkat partisipasinya yaitu penanganan sampah kategori tinggi, penanganan air limbah kategori rendah, membersihkan lingkungan kategori tinggi, dan untuk pembayaran uang retribusi kebersihan tergolong rendah. Upaya mengoptimalkan partisipasi pedagang kaki lima antara lain penambahan fasilitas penunjang, pengawasan berkala, mendata pedagang, pemungutan uang retribusi kebersihan kepada seluruh pedagang, dan mengadakan sosialisai program kebersihan.
\end{abstract}

\section{Kata kunci : Partisipasi, Pedagang Kaki Lima, Pengelolaan}

\section{ABSTRACT}

This study aims to determine the form and level of participation of street vendors and government efforts to optimize the participation of street vendors in environmental hygiene management. The research method used in thesis writing is a qualitative descriptive method, but it is not purely qualitative. The results showed that there were four forms of street vendor participation along with the level of participation, namely high waste magement, low waste management, cleaning high environments, and low paying retribution fees. Efforts to optimize the participation of street vendors include the addition of supporting facilities, periodic supervision, data collection of traders, collection of cleaning retribution money to all traders, and holding a socialization of cleaning programs.

Keywords: Participation, Stereet vendors, Management

\footnotetext{
${ }^{1}$ Artikel ini ditulis dari skripsi penulis dengan judul Partisipasi Pedagang Kaki Lima Dalam Pengelolaan Kebersihan Lingkungan di Kota Solok. Untuk wisuda September 2018 dengan ${ }^{2}$ Pembimbing I Dr. Paus Iskarni, M.Pd dan Pembimbing II Hendry Frananda, S.Pi, M.Sc.
} 


\section{PENDAHULUAN}

Pembangunan perkotaan yang berwawasan lingkungan merupakan suatu paradigma pembangunan yang dilaksanakan oleh negara-negara di dunia termasuk di dalamnya Indonesia. Konsep pembangunan yang berwawasan lingkungan jika dikaitkan dengan pembangunan perkotaan adalah pembangunan yang tidak hanya mementingkan pembangunan fisik semata, tetapi juga memperhatikan kelestarian lingkungan. Pembangunan yang berlandaskan kepada aspek lingkungan ini merupakan bagian dari pembangunan yang berkelanjutan.

Budiharjo (1999) mengemukakan bahwa "Pembangunan yang berkelanjutan adalah pembangunan yang mampu memenuhi kebutuhan masyarakat masa kini tanpa mengabaikan generasi masa mendatang untuk dapat memenuhi kebutuhannya". Dalam menerapkan konsep pembangunan perkotaan yang berwawasan lingkungan. Salah satu aspek yang menjadi perhatian pemerintah Kota Solok adalah kebersihan lingkungan kota. Hal tersebut disebabkan karena kebersihan lingkungan perkotaan mempunyai makna tersendiri dalam melaksanakan pembangunan kota.

Ukuran keberhasilan pembangunan suatu kota tidak hanya diukur secara ekonomi dan fisik saja tetapi juga dilihat dari peran pedagang kaki lima dan upaya pemerintah dalam menciptakan suatu lingkungan yang bersih. Lingkungan kota yang bersih tidak hanya menunjukan nilai estetika kota itu sebagai kota yang nyaman, indah dan asri serta sehat yang dapat menjadi daya tarik tersendiri akan tetapi juga dapat mengurangi atau mencegah terjadinya banjir akibat kerusakan lingkungan yang disebabkan oleh manusia yang apatis terhadap lingkungan.

Seiring bertambahnya jumlah penduduk dan perkembagan Kota Solok yang semakin pesat serta kurang tersedianya lapangan perkejaan di sektor formal bagi para penduduk tersebut, akan menyebabkan mereka mencoba mencari lapangan pekerjaan lain di sektor informal di saat krisis ekonomi yang melanda Indonesia sampai saat sekrang ini. Keberadaan sektor informal pada saat ini adalah para pedagang kaki lima apabila dikaitkan dengan pembangunan perkotaan sendiri mempunyai dampak positif dan dampak negati.

Ramli (1991) mengemukakan bahwa "Pedagang kaki lima dapat menjadi negatif apabila pedagang kaki lima di pandang sebagai suatu hal yang dapat menimbulkan kemacetan lalu lintas, gangguan ketertiban, kebersihan (sampah), keindahan dan sebagainya". Dalam penetaan lingkungan kota, pedagang kaki lima yang termasuk dalam salah satu sektor informal yang sering menjadi permasalahan tersendiri. Pada saat ini kita dapat melihat hampir disetiap ruas-ruas jalan utama Kota Solok terdapat pedagang kaki lima yang berdagang pada malam hari, sebagian ada yang berjualan di pelataran parkir Pasar Raya. Jenis barang yang yang dijual oleh PKL/Pedagang Malam kebanyakan adalah makanan dan minuman (kuliner). Ada juga beberapa pedagang yang menjual pakaian, 
asesoris/mainan, kaset/VCD, pulsa/kartu telepon, dan lainlain. Waktu berjualan pada malam hari hingga tengah malam namun persiapan menggelar barang dagangannya sudah dimulai dari sore karena tenda/tempat berjualan mereka bersifat buka-pasang (tidak permanen). Setelah selesai berjualan pada tengah malam, mereka membuka tenda/tempat berjualan dan akan memasangnya esok hari ketika akan berjualan kembali. Bisa saja di tempat yang sama tapi bisa juga di tempat yang berbeda. Dilihat dari tingkat urgensinya, keberadaan para pedagang kaki lima tersebut dapat berakibat mengurangi keindahan kota dimana dalam beraktifitas masih ada dari mereka yang kurang memperhatikan masalah lingkungan, utamanya kebersihan dengan membuang sampah disembarang tempat dari berbagai aktifitas yang mereka mereka lakukan sehingga menciptakan suatu bentuk lingkungan yang kotor dan jorok serta memungkinkan terciptanya biang penyakit akibat dari keadaan lingkungan di tempat mereka melakukan aktifitasnya sebagai pedagang.

Berbagai gambaran kondisi disekitar beberapa ruas jalan utama tersebut diakibatkan masih ada pedagang kaki lima yang tidak memelihara dan menjaga kebersihan lingkungan dengan membiarkan sampah berserakan di sekitar beberapa ruas jalan. Keadaan tersebut tentunya menciptakan kondisi lingkungan yang tidak bersih dan dapat mencemari lingkungan sekitarnya yang tentunya membawa dampak tersendiri bagi keberadaan lokasi tersebut oleh Pemerintah Kota Solok yang diupayakan sebagai tempat rekreasi warga masyarakat, apabila hal tersebut tidak ditanggulangi akan menyebabkan turunnya minat masyarakat berkunjung kelokasi tersebut. Untuk itu dalam mengelola kebersihan lingkungan dilokasi tersebut diperlukan bentuk dan tingkat partisipasi pedagang kaki lima yang menggunakan lokasi tersebut untuk mendukung upaya Pemerintah Kota Solok dalam menciptakan suatu kondisi lingkungan yang bersih. Sesuai dengan Peraturan Daerah Kotamadya Tingkat II Solok Nomor 5 Tahun 2017 Bab VI Pasal 31 tentang Penataan dan pemberdayaan Padagang Kaki Lima, yang menyebutkan bahwa setiap pedagang kaki lima menyediakan tempat sampah, tempat cuci piring, dan tempat limbah sementara untuk PKL yang berjualan makanan dan minuman.

Partisipasi dalam hal ini adalah peran pedagang kaki lima dalam pengelolaan kebersihan lingkungan yang telah diatur dalam Undang-Undang Nomor 23 Tahun 1999 tentang Lingkungan Hidup dan Peraturan Daerah Kota Solok Nomor 13 Tahun 2012 tentang Pengelolaan Kebersihan di Kota Solok. Upaya pemerintah juga sangat diperlukan dalam mengoptimal pelaksanaan partisipasi pedagang kaki lima. Dengan melibatkan partisipasi pedagang kaki lima dalam pembangunan lingkungan perkotaan diharapkan pedagang kaki lima mempunyai kesadaran, kepedulian dan rasa ikut memiliki terhadap lingkungan sekitarnya. Wujud kesadaran dan kepedulian pedagang kaki lima dapat dilakukan melalui usaha menjaga, memelihara dan meningkatkan kebersihan lingkungan sekitarnya 
sehingga dapat menciptakan suatu lingkungan kota yang bersih, nyaman, indah dan asri agar kota tersebut lingkungannya tidak saja layak huni tetapi juga menciptakan kesan yang nyaman. Hal tersebut dapat terlaksana dengan baik apabila ada partisipasi dari para pedagang kaki lima itu sendiri untuk menciptakan kondisi tersebut. "Partisipasi berasal dari bahasa Inggris to participate yang berarti ikut serta, mengambil bagian atau terkadang diartikan juga sebagai berperan serta" (Soeganda, 1997).

Hal ini sejalan dengan pendapat yang dikemukakan oleh Hoosstede dalam Khairuddin (1992) yaitu "Partisipasi berarti ambil bagian dalam satu atau lebih dari suatu proses". Pedagang Kaki Lima adalah "Pedagang kecil yang berjualan di suatu tempat umumnya seperti di tepi jalan, tamantaman, emper-emper toko serta pasarpasar tanpa ijin yang resmi dari pemerintah" yang diutarakan oleh Karafir (1997). Pengelolaan adalah "proses melakukan kegiatan tertentu dengan menggerakkan tenaga orang lain" Sari dalam Efrida (2012). "Manusia perlu menjaga kebersihan lingkungan dan kebersihan diri agar sehat, tidak bau, tidak malu, tidak menyebarkan kotoran, atau menyebarkan kuman penyakit bagi diri sendiri maupun orang lain", Raharjo dalam Jaswita (2006). Nurmandi mengemukakan bahwa "Lingkungan perkotaan mencakup dimensi yang sangat luas dimana didalamnya meliputi dimensi sosial, dimensi ekonomi dan dimensi politik dari dampak urbanisasi yang begitu cepat".

\section{METODE PENELITIAN}

Berdasarkan rumusan masalah dan tujuan dari penelitian, maka permasalahan yang diteliti yaitu untuk mengetahui partisipasi pedagang kaki lima dalam pengelolaan kebersihan lingkunga di Kota Solok maka penelitian ini termasuk penelitian deskriptif. Ditinjau dari segi sifat dan pendekatan yang digunakan dalam penelitian ini maka penelitian ini tergolong jenis penelitian deskriptif kualitatif tapi tidak kualitatif murni karena dalam penelitian ini masih ada beberapa hal pengambilan data dengan melakukan pengukuran seperti pengambilan titik koordinat pedagang dan mengukur panjang jalan lokasi penelitian. Responden merupakan subjek penelitian atau orang yang bisa dijadikan sumber informasi. Setiap subjek yang diwawancarai adalah orang yang bisa mewakili setiap data yang diperlukan. Adapun yang menjadi subjek dalam penelitian ini adalah seluruh pedagang kaki lima yang berada di Jalan Kh. A. Dahlan dan Jalan Berok, yang berjumlah 57 pedagang yang dibagi berdasarkan pedagang makanan yang berjumlah 41 pedagang, pedagang minuman yang berjumlah 11 pedagang, dan pedagang lainya yang berjumlah 5 pedagang. 
Berdasarkan persebaran pedagang kaki lima di kedua ruas jalan utama di Kota Solok dapat kita lihat pada tabel sebaran pedagang menurut kategori dagangan di bawah ini:

Tabel 1. Disribusi sebaran pedagang menurut kategori dagangangan

\begin{tabular}{|c|c|c|c|c|c|}
\hline \multirow[t]{2}{*}{ No } & \multirow[t]{2}{*}{ Kategori } & \multirow[t]{2}{*}{ Jenis } & \multicolumn{2}{|c|}{ Area/Lokasi } & \multirow[t]{2}{*}{ Jumlah } \\
\hline & & & $\begin{array}{l}\text { Jalan } \\
\text { KH. A. } \\
\text { Dahlan }\end{array}$ & $\begin{array}{l}\text { Jalan } \\
\text { Berok }\end{array}$ & \\
\hline \multirow[t]{8}{*}{1} & \multirow[t]{8}{*}{ Makanan } & Nasi Ampera & & 3 & 3 \\
\hline & & $\begin{array}{l}\text { Pecel Lele/Ayam/Bebek } \\
\text { /ayam penyet }\end{array}$ & 5 & & 5 \\
\hline & & $\begin{array}{l}\text { Nasi Goreng/Martabak } \\
\text { mesir/Mie Rebus }\end{array}$ & 3 & 1 & 4 \\
\hline & & $\begin{array}{l}\text { Gorengan/Pempek/Pisang } \\
\text { Keju/Jagung/Bakso } \\
\text { Bakar/Pempek }\end{array}$ & 9 & 4 & 13 \\
\hline & & Sate Biasa/Madura & 2 & 2 & 4 \\
\hline & & Fried Chicken & 2 & 2 & 4 \\
\hline & & Bakso & 1 & 1 & 2 \\
\hline & & $\begin{array}{l}\text { Roti Bakar/ /Martabak/ } \\
\text { Manis/Kebat }\end{array}$ & 5 & 1 & 6 \\
\hline \multirow[t]{3}{*}{2} & \multirow[t]{3}{*}{ Minuman } & STMJ/ Warkop & 4 & 2 & 6 \\
\hline & & Jus/Jasuke/Es kepal milo & 3 & 1 & 4 \\
\hline & & Air Kacang/Jamu/Cincau & & 1 & 1 \\
\hline \multirow[t]{3}{*}{3} & \multirow[t]{3}{*}{ Lainya } & Kelontong Gerobak & & 2 & 2 \\
\hline & & Kaset/VCD & & 2 & 2 \\
\hline & & Kios Buah & & 1 & 1 \\
\hline & Total & & 34 & 23 & 57 \\
\hline
\end{tabular}

Teknik pengumpulan data yang digunakan dalam penelitian ini yaitu dengan wawancara kuesioner dan dokumentasi. Sedangkan teknik analisis data dalam penelitian ini yaitu teknik reduksi data, display data, interprestasi data dan penganbilan kesimpulan. Keabsahan data yang digunakan yaitu tringulasi, pemeriksaan teman sejawat melalui diskusi.

Tabel 2. Penilaian Tingkat Partisipasi Menurut Metode Gutman

\begin{tabular}{|c|l|l|}
\hline No & \multicolumn{1}{|c|}{ Penilaian } & \multicolumn{1}{|c|}{ Tingkat Parisipasi } \\
\hline 1 & $<50 \%$ & Rendah \\
\hline 2 & $<=50 \%$ & Sedang \\
\hline 3 & $>50 \%$ & Tinggi \\
\hline
\end{tabular}

HASIL DAN PEMBAHASAN

Penelitian tentang partisipasi pedagang kaki lima dalam pengelolaan kebersihan lingkungan di Kota Solok
Untuk menentukan tingkat partisipasi peneliti memberi penilaian atau skoring terhadap bentuk partisipasi pedagang kaki lima dalam pengelolaan kebersihan berdasarkan pendekatan dengan metode Gutman, penilaian tersebut dapat dilihat pada tabel di bawah ini :
(Studi kasus di beberapa ruas jalan utama Kota Solok), tepatnya di jalan KH. A. Dahlan dan jalan Berok. 
Kota Solok secara astronomis berada pada posisi $0^{0} 32^{\prime}-1^{0} 45^{\prime}$ lintang selatan dan antara $100^{0} 32^{\prime}-101^{0} 41^{\prime}$ bujur timur. Kota Solok terbagi 15 kelurahan, dapat dilihat pada peta di bawah ini :

Gambar 1 Peta Atministrasi Kota kolok

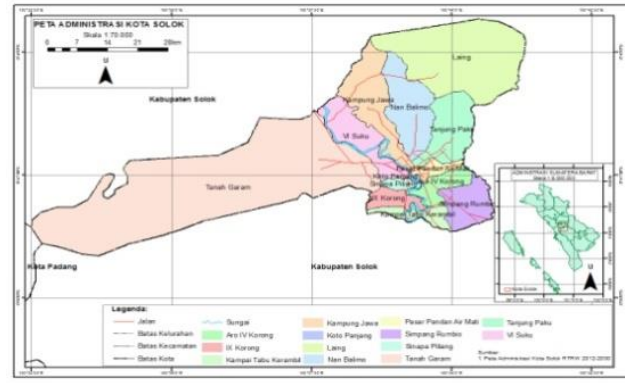

Pertumbuhan penduduk Kota

Solok cukup besar, pada tahun 2007 jumlah penduduk Kota Solok 57.120 jiwa, dengan laju pertumbuhan penduduk selama sepuluh tahun terakhir jumlah nya sebesar $2.12 \%$ setiap tahun. Jumlah penduduk Kota Solok pada tahun 2010 menjadi 59.317 jiwa. Pertumbuhan penduduk yang semakin cepat, mengakibatkan kurangnya lapangan pekerjaan di sektor formal maka penduduk akan mencari lapangan pekerjaan di sektor informal yang didalam nya mencakup kegiatan pedagang kaki lima, maka para penduduk yang yang melakukan kegiatan di sektor informal tersebut mereka memerlukan tempat, oleh karena itu pemerintah Kota Solok menyediakan lokasi dibeberapa ruas jalan utama untuk pedagang kaki lima yang berjualan di malam hari. Keberadaan mereka sangat berdampak terhadap kebersihan lingkungan, karena mereka menghasilkan sampah dari kegiatan yang mereka lakukan oleh sebab itu perlu adanya partisipasi pedagang kaki lima dalam pengelolaan kebersihan agar nantinya sesuai yang dengan yang telah di harapkan oleh pemerintah dan masyarakat yaitu suatu lingkungan perkotaan yang bersih di Kota Solok.

Untuk persebaran pedagang kaki lima di Kota solok dapat kita lihat pada peta di bawah ini :

Gambar 2. Peta Persebaran PKL

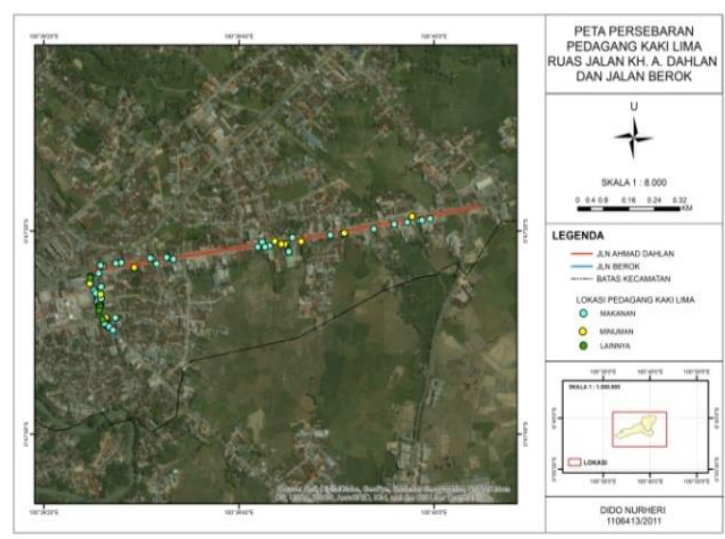

\section{Analisis Tentang Bentuk dan Tingkat Partisipasi Pedagang Kaki Lima Dalam Pengelolaan Kebersihan lingkungan}

Berikut ini digambarkan bentuk deskripsi pedagang kaki lima dalam partisipasinya menciptakan dan memelihara kebersihan lingkungan di tempat mereka berjualan.

\section{Penanganan Sampah}


Salah satu wujud partisipasi pedagang kaki lima dalam kebersihan lingkungan dalam penelitian ini adalah kesadaran pedagang kaki lima dalam membuang sampah dengan memperhatikan aspek-aspek kesehatan dan kebersihan lingkungan.

Untuk dapat dengan mudah melihat partisipasi pedagang kaki lima dalam penanganan samapah dapat di lihat pada tabel di bawah ini :

Tabel 3 Disribusi Dalam Penanganan Sampah

\begin{tabular}{|l|c|c|}
\hline $\begin{array}{l}\text { Penanganan } \\
\text { Sampah }\end{array}$ & Frekuensi & Persentase ( \% ) \\
\hline $\begin{array}{l}\text { Dikumpulkan } \\
\text { dalam } \\
\text { kantong/wadah } \\
\text { lalu di buang } \\
\text { kekontainer } \\
\text { sampah }\end{array}$ & $\mathbf{3 2}$ & $\mathbf{5 6 . 1 4}$ \\
Dikumpulkan \\
dalam \\
kantong/wadah \\
lalu di simpan \\
didepan \\
gerobak untuk \\
di angkut \\
petugas
\end{tabular}

Sumber : Data hasil penelitian Mei 2018

Gambaran yang dapat diperoleh dari tabel 3 di atas di ketahui bahwa sebagian besar responden $(56,14 \%)$ dalam penanganan sampah dilakukan dengan dikumpul dalam kantong/wadah lalu di buang lansung ke kontainer sampah. Berdasarkan penilaian yang peneliti yang telah tentukan untuk tingkat dari bentuk partisipasi. Hal tersebut menggambarkan bahwa partisipasi pedagang kaki lima dalam kebersihan lingkungan khususnya penanganan sampah umumnya tergolong tinggi.

Untuk dapat membedakan para pedagang yang berpatisipasi dalam penanganan sampah dapat kita lihat pada peta di bawah ini :

\section{Gambar 3 Peta Penanganan Sampah}

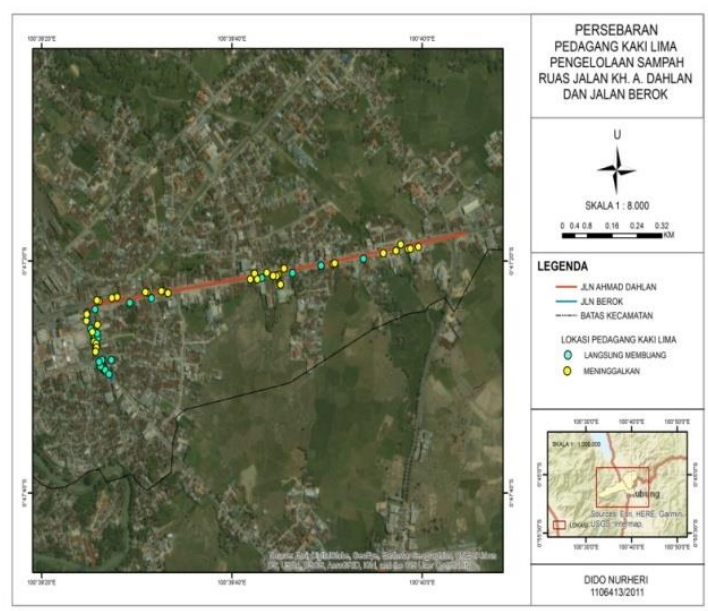

\section{Penanganan air Limbah}

Partisipasi pedagang kaki lima dalam membuang air limbah merupakan wujud partisipasi/peran serta mereka dalam kebersihan lingkungan. Indikator partisipasi pedagang kaki lima dalam penanganan air limbah adalah sejauh mana para pedagang kaki lima dalam membuang air limbah bekas cucian mereka dengan menggunakan pasilitas saluran drainase/got yang telah tersedia dan berdasar syarat kesehatan dan kebersihan lingkungan.

Untuk dapat dengan mudah melihat partisipasi pedagang kaki lima dalam penanganan air limbah dapat di lihat pada tabel di bawah ini :

Tabel 4 Disribusi Dalam Penanganan Air Limbah

\begin{tabular}{|l|c|c|}
\hline $\begin{array}{l}\text { Penanganan } \\
\text { Air Limbah }\end{array}$ & Frekuensi & Persentase ( \% ) \\
\hline $\begin{array}{l}\text { Air limbah } \\
\text { dipisahkan } \\
\text { dengan } \\
\text { sampah padat }\end{array}$ & $\mathbf{2 0}$ & $\mathbf{3 5 , 0 9}$ \\
\hline
\end{tabular}




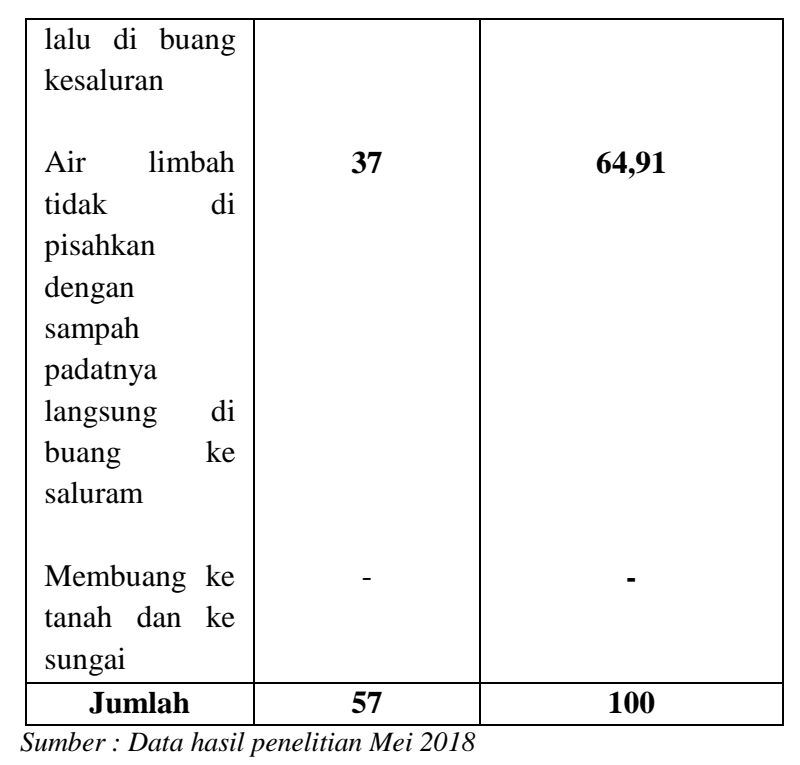

Memperhatikan tabel 4 di atas, dapat digambarkan bahwa partisipasi pedagang kaki lima dalam penganan air limbah mereka pada umumnya masih tergolong rendah, berdasar penilaian tingkat dari bentuk partisipasi menunjukan bahwa sekitar 35,09\% pedagang yang memisahkan limbah padatnya.

Untuk dapat membedakan para pedagang yang berpatisipasi dalam penanganan air limbah dapat kita lihat pada peta di bawah ini :

Gambar 3 Peta Penanganan Air Limbah

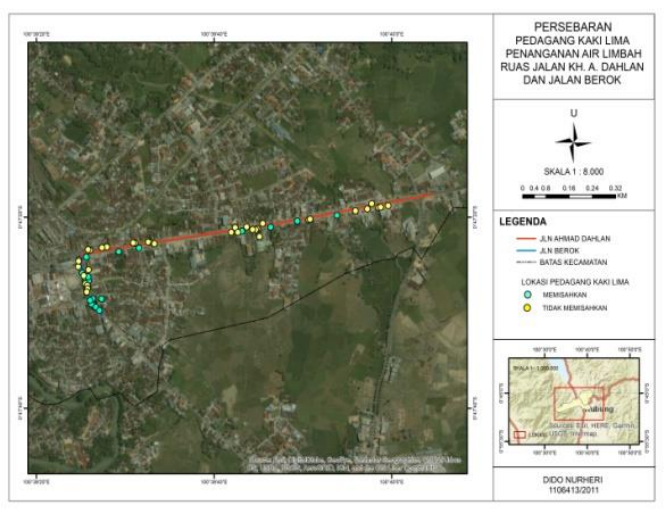

\section{Membersihkan Linkungan}

Aktivitas responden secara berkala dalam membersihkan lingkungan di sekitar tempat berjualan merupakan salah satu wujud partisipasi mereka yang diasumsikan sebagai bentuk kepedulian responden terhadap kebersihan lingkungan.

Untuk dapat dengan mudah melihat partisipasi pedagang kaki lima dalam membersihkan lingkungan dapat di lihat pada tabel di bawah ini :

Tabel 5

Disribusi Dalam Membersihkan Lingkungan

\begin{tabular}{|c|c|c|}
\hline $\begin{array}{c}\text { Penerimaan Membersikan } \\
\text { Lingkungan }\end{array}$ & Frekuensi & Persentase (\%) \\
\hline Setiap hari & 57 & 100 \\
\hline Seminggu sekali & - & - \\
\hline Tidak pernah & - & - \\
\hline Jumlah & 57 & 100 \\
\hline
\end{tabular}

Gambaran yang ditunjukan tabel 5 di atas menujukan bahwa Pedagang kaki lima yang berada di Jalan Kh. A. Dahlan dan Jalan Berok. Seluruh responden membersihkan lingkungan di sekitar tempat merka berjualan, dari hasil pengamatan penulis mengkategorikan bahwa partisipasi pedagang kaki lima tergolong tinggi berdasarkan penilaian yang diberikan peneliti.

Untuk dapat membedakan para pedagang yang berpatisipasi dalam membersihkan lingkungan dapat kita lihat pada peta di bawah ini : 
Gambar 5

Peta Membersikan Lingkungan

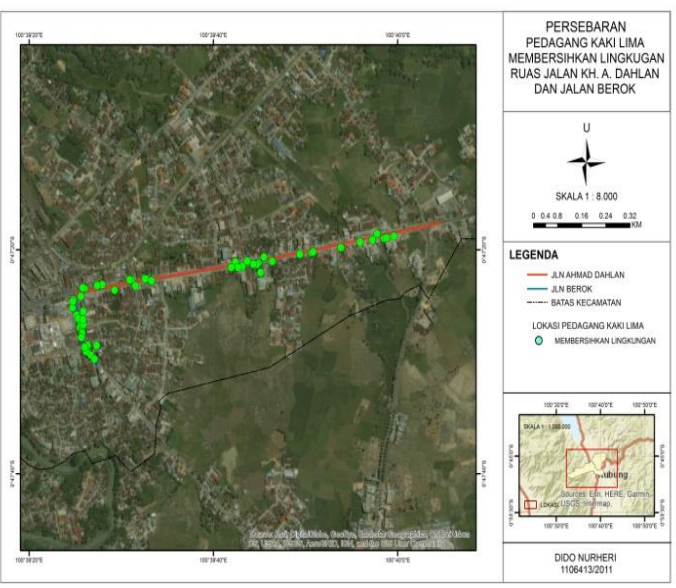

\section{Pembayaran Retribusi}

Salah satu faktor yang dapat menunjang pelaksanaan program kebersihan lingkungan adalah retribusi kebersihan. Hal tersebut disebabkan keterbatasan pemerintah dalam membiayai dana operasional untuk pengelolaan kebersihan. Untuk itu, partisipasi pedagang kaki lima dalam membayar iuran kebersihan sangat diharapkan oleh pemerintah guna menunjang pengelolaan kebersihan. Iuran tersebut dikumpulkan oleh pengelola pedagang kaki lima/pedagang malam yang dibantu oleh pihak terkait yang telah ditunjuk oleh pemerintah Kota Solok.

Untuk dapat dengan mudah melihat partisipasi pedagang kaki lima dalam pembayaran retribusi dapat di lihat pada tabel di bawah ini :

Tabel 6 Disribusi Dalam Pembayaran Retribusi

\begin{tabular}{|l|c|c|}
\hline $\begin{array}{c}\text { Retribusi } \\
\text { Kebersihan }\end{array}$ & $\begin{array}{c}\text { Freku } \\
\text { ensi }\end{array}$ & $\begin{array}{c}\text { Persentase ( } \\
\%)\end{array}$ \\
\hline Selalu & 19 & 33,33 \\
Kadang-kadang & 18 & 31,58 \\
Tidak pernah & 20 & 35,09 \\
\hline \multicolumn{1}{|c|}{ Jumlah } & 57 & 100 \\
\hline
\end{tabular}

Sumber : Data hasil penelitian Mei 2018

Pada tabel 6 di atas berdadarkan penilaian yang diberikan peneliti menunjukkan bahwa sebagian besar responden dalam membayar retribusi kebersihan berpartisipasi rendah hal ini ditunjukan dengan hanya 33,33\% selalu membayar, $31,58 \%$ kadang-kadang membayar dan yang tidak pernah membayar retribusi sebanyak 35,09\%. Keadaan tersebut disebabkan keaktifan dalam membayar retribusi kebersihan tergantung terhadap kesadaran responden dalam membayar uang Retribusi. Kalau di lihat keuntungan yang diperoleh responden dalam setiap harinya tidak ada pedagang kaki lima yang tidak mampu untuk membayar uang retribusi kebersihan. Dari hasil pengamatan di lapangan uang kebersihan hanya sekitar Rp 5000,00-Rp 7000,00 perminggu dan Rp 50.000,00-Rp $60.000,00$ perbulan sudah termasuk pajak untuk pedagang yang berpendapatan tinggi. Wawancara yang dilakukan kepada pedagang kaki lima beberapa dari mereka mengatakan bahwa mereka ada yang sudah langsung membawa sampah mereka tanpa menungggu petugas kebersihan untuk mengumpulkan oleh karena hal itu mereka tidak perlu lagi untuk membayar uang retribusi kebersihan ada juga dari mereka yang mengatakan tidak lagi perlu membayar uang kebersihan karena mereka berjualan di tepi jalan depan ruko orang, juga ada yang mengatakan lupa. Akan tetapi retribusi kebersihan merupakan iuran wajib bagi semua pedagang yang berjualan di Jalan Kh. A. Dahlan dan Jalan Berok. 
Untuk dapat membedakan para pedagang yang berpatisipasi dalam membersihkan lingkungan dapat kita lihat pada peta di bawah ini :

\section{Gambar 6 Peta Pembayaran Retribusi}

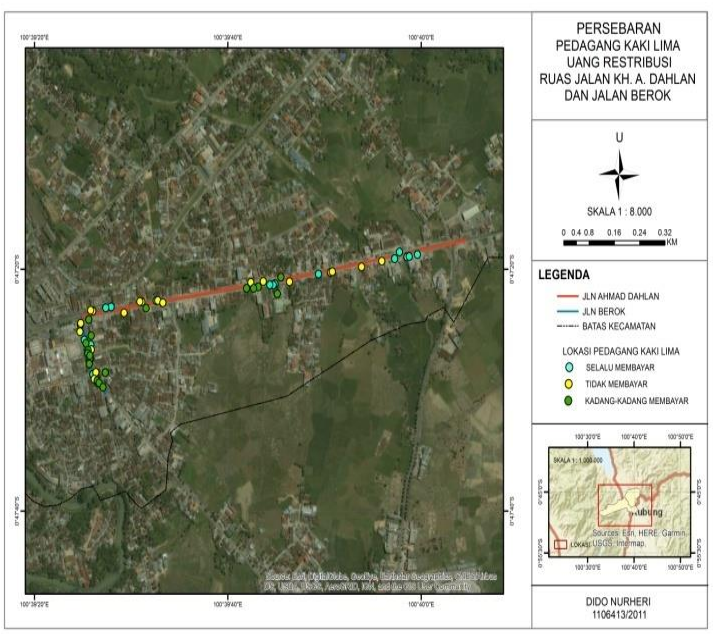

Berdasarkan penelitian yang telah dilakukan mengenai partisipasi pedagang kaki lima dalam pengelolaan kebersihan lingkungan di Kota Solok

\section{Bentuk Partisipasi Pedagang Kaki Lima Dalam Pengelolaan Kebersihan di Kota Solok}

Berdasarkan hasil wawancara dengan mengunakan kuesioner yang dilakukan kepada para pedagang kaki lima di Kota Solok. Maka ditemukan bahwa ada 4 bentuk partisisi yang dilakukan oleh pedagang kaki lima dalam pengelolaan kebersihan lingkungan di lokasi mereka berjualan, dari data yang diperoleh dari penelitian ini bentuk partisipasi pedagng kaki lima yaitu :

a. Penanganan sampah merupakan salah satu bentuk partisipasi yang sangat harus diperhatikan oleh para pedagang kaki lima, seandainya hal ini tidak diperhatikan secara seksama antara pedagang, masyarakat dan pemerintah akan memberikan suatu efek yang buruk terhdap kebersiahan lingkungan sekitar. Bentuk penanganan sampah yang dilakukan oleh pedagang kaki lima adalah mengumpulkan sampah dalam kantong/wadah lalu langsung membuangnya ke kontainer sampah. Berdasarkan data yang diperoleh sebanyak 21 pedagang makanan, 7 pedagang minuman,dan 4 pedagang lainya sudah mengumpulkan sampah dalam kantong/wadah lalu langsung membuang ke kontainer sampah, sebanyak 20 pedagang makanan, 4 pedagang minuman, dan 1 pedagang lainnya mereka belum melakukan partipasi dengan baik, mereka hanya mengumpulkan sampah dalam kantong/wadah lalu meninggal kan di gerobak mereka. Dari hasil wawancara dari mereka yang tidak mengantarkan ke gerobak sampah, mereka mengatakan untuk apalagi mengantarkan ke gerobak karena sudah ada petugas. Hal ini menunjukan sebagian dari mereka telah berpatisipasi tanpa harus menunggu petugas kebersihan.

b. Penanganan air limbah merupakan suatu hal yang juga sangat harus diperhatikan oleh pedagang kaki lima, seandainya dalam penanganan air limbah yang salah dapat mengganggu aliran saluran drainase/got hal ini mengakibatkan terjadi nya banjir luapan air drainase/got. Bentuk penanganan 
air limbah yang di lakukan oleh pedagang kaki lima adalah air limbah di pisahkan dengan limbah padatnya lalu dibuang kesaluran Berdasarkan hasil data yang di peroleh, sebanyak 14 pedagang makanan, 5 pedagang minuman, 1 pedagang lainnya sudah memisahkan air limbah dengan limbah padatnya lalu dibuang kesaluran, sebanyak 27 pedagang makanan, 6 pedagang minuman, 4 pedagang lainnya mereka belum melakukan partipasi dengan baik, mereka belum memisahkan air limbah dengan limbah padatnya lalu langsung membuang kesaluran.

c. Membersihkan lingkungan merupakan yang harus dilakukan oleh pedagang supaya lingkungan mereka berjualan tetap terjaga kebersihannya Berdasarkan hasil data yang diperoleh dari wawancara dengan pedagang kaki lima, seluruh dari mereka yang di wawancarai sudah membersihkan lingkungan setiap hari di tempat mereka berjualan.

d. Pembayaran retribusi kebersihan merupakan suatu bentuk dari partisipasi uang kebersihan sangat berguna untuk mengatasi masalah lingkungan karena dapat mendukung program pemerintah dalam pengelolaan kebersihan lingkungan. Bentuk pembayaran retribusi kebersihan adalah selalu membayar. Hasil data yang diperoleh wawancara dengan para pedagang maka dalam pembayaran uang retribusi kebersihan, sebayak
12 pedagang makanan, 7 pedagang minuman, 1 pedagang lainya mereka selalu membayar, sebanyak 17 pedagang makanan, 1 pedagang lainnya mereka kadangkadang membayar, dan sebanyak 12 pedagang makanan, 4 pedagang minuman, 3 pedagang lainya mereka tidak pernah membayar uang retribusi kebersihan. Uang retribusi merupakan iuran wajib seluruh pedagang kaki lima yang berdagang di Jalan Kh. A. Dahlan dan Jalan Berok.

\section{Tingkat Partisipasi Pedagang Kaki Lima Dalam Pengelolaan Kebersihan Lingkungan di Kota Solok}

Berdasarkan penilaian yang diberikan peneliti tentang tingkat dari bentuk dan hasil analisis data penelitian ini maka tingkat partisipasi pedagang kaki lima sudah tergolong sedang, hal ini dapat dilihat tingkat dari bentuk partisipasi yang mereka lakukan yaitu :

a. Penanganan sampah, dari hasil analisis data yang telah dilakukan maka tingkat partisipasi pedagang kaki lima tergolong tinggi dalam penanganan sampah, hal ini dapat dilihat sebanyak 56,14 \% pedagang sudah megumpulkan sampah dan langsung membuang ke kontainer sampah.

b. Penaganan air limbah, dari hasil analisis data yang dilakukan maka tingkat partisipasi pedagang kaki lima tergolong rendah dalam penaganan air limbah, hal ini dapat dilihat sebanyak 20 pedagang atau sekitar 35,09 \%,dari total jumlah pedagang mereka memisahkan air limbah dengan sampah padatnya 
dan sebanyak $64,91 \%$ pedagang masih membuang langsung air limbah tanpa memisahkan sampah padatnya ke saluran drainase/got.

c. Membersihkan lingkungan, hasil analisis data yang telah dilakukan maka tingkat partisipasi pedagang kaki lima tergolong tinggi dalam membersihkan lingkungan, hal ini dapat dilihat bahwa seluruh pedagang kaki lima telah membersihkan lingkungan tempat mereka berjualan setiap hari.

d. Pembayaran retribusi kebersihan, dari hasil analisis data telah dilakukan maka tingkat partisipasi pedagang kaki lima tergolong rendah dalam pembayaran rertribusi kebersihan, hal ini dapat dilihat sebanyak 33,33 \% pedagang yang selalu membayar uang retribusi kebersihan, 31,58\% kadang-kadang membayar, dan $35,09 \%$ tidak pernah membayar.

3. Upaya Pemerintah Mengoptimalkan Partisipasi Pedagang Kaki Lima Dalam Pengelolaan Kebersihan Lingkungan di Kota Solok

Dari hasil analisis data penelitian ini maka partisipasi pedagang kaki lima dalam kebersihan lingkungan sampai saat ini sudah tergolong sedang, akan tetapi pelaksanaannya belum optimal. Hal tersebut terlihat dari lokasi tempat mereka berdagang masih ada sampah yang bertebaran sehingga menunjukan keadaan tersebut menampakkan suasana kurang bersih.

Demikian halnya kondisi lingkungan sekitar Jalan Kh. A. Dahlan dan Jalan Berok yang kondisi kedua ruas jalan tersebut masih terlihat ada beberapa sampah masih bertebaran, keadaan tersebut selain disebabkan oleh faktor internal pedagang yaitu pedagang hanya mempedulikan sampah yang ada di sekitar tempat merka berjualan, juga disebabkan oleh faktor eksternal yaitu masih belum tercukupi semua fasilitas kebersihan lingkungan di sekitar lokasi tempat mereka berjualan serta masih kurangnya kesadaran dan pengetahuan pedagang kaki tentang pengelolaan kebersihan lingkungan dan kurangnya tindakan pengelola pedagang kaki lima terhadap terhadap pengumutan uang retribusi kebersihan.

Berdasarkan uraian di atas maka untuk mengoptimalkan partisipasi pedagang kaki lima dalam pengelolaan kebersihan lingkungan di Kota Solok, pemerintah perlu melakukan upayaupaya sebagai berikut :

a. Penambahan fasilitas penunjang kebersihan seperti tong sampah maupun kontainer sampah yang letaknya tidak terlalu jauh dengan lokasi tempat berjualan para pedagang kaki lima

b. Pengawasan secara berkala terhadap aktivitas para pedagang kaki lima maupun terhadap fasilitas yang ada serta penerapan sanksi bagi pihak-pihak yang tidak mematuhi peraturan yang berlaku sehingga kebersihan lingkungan dapat tetap terjaga.

c. Pemerintah seharusnya mendata kembali seluruh pedagang kaki lima yang berdagang pada malam hari supaya para pedagang tersebut dapat mengikuti program kebersihan secara terorganisir. 
d. Pemerintah harus melakukan pemungutan uang retribusi kebersihan kepada seluruh pedagang kaki lima yang berdagang malam dan menberikan sangsi kepada pedagang yang malas membayar uang kebersihan.

e. Pemerintah harus mengadakan sosialisasi program kebersihan secara rutin dan mendata pedagang yang hadir dalam sosialisasi tersebut agar menumbuhkan kesadaran terhadap pedagang kaki lima dalam pengeloaan kebersihan lingkungan.

\section{PENUTUP}

\section{Kesimpulan}

Berdasarkan analisis data dan pembahasan yang telah dikemukakan diambil kesimpulan tentang partisipasi pedagang kaki lima dalam pengelolaan kebersihan lingkungan di Kota Solok sebagai berikut:

1. Bentuk partisipasi pedagang kaki lima yang berjualan di beberapa ruas jalan utama Kota Solok Tepatnya di Jalan Kh. A. Dahlan dan Jalan Berok dalam penegelolaan kebersihan lingkungan ada empat yaitu dalam penanganan sampah, penganan air limbah, membersihkan lingkungan, dan membayar uang retribusi kebersihan.

2. Tingkat Partisipasi pedagang kaki lima yang berjualan di beberapa ruas jalan utama Kota Solok Tepatnya di Jalan Kh. A. Dahlan dan Jalan Berok dalam pengelolaan kebersihan lingkungan, peneliti menyimpulkan bahwa tingkat dari bentuk partisipasi dalam penanganan sampah kategori tinggi, penanganan air limbah kategori rendah, membersihkan lingkungan kategori tinggi, dan untuk pembayaran uang retribusi kebersihan tergolong rendah.

3. Upaya yang dapat dilakukan pemerintah untuk mengoptimalkan partisipasi pedagang kaki lima dalam pengelolaan kebersihan lingkungan dapat ditempuh melalui:

a. Penambahan fasilitas penunjang kebersihan seperti tong sampah maupun kontainer sampah yang letaknya tidak terlalu jauh dengan lokasi tempat berjualan para pedagang kaki lima.

b. Pengawasan secara berkala terhadap aktivitas para pedagang kaki lima maupun terhadap fasilitas yang ada serta penerapan sanksi bagi pihak-pihak yang tidak mematuhi peraturan yang berlaku sehingga kebersihan lingkungan dapat tetap terjaga.

c. Pemerintah seharusnya mendata kembali seluruh pedagang kaki lima yang berdagang pada malam hari supaya para pedagang tersebut dapat mengikuti program kebersihan secara terorganisir.

d. Pemerintah harus melakukan pemungutan uang retribusi kebersihan kepada seluruh pedagang kaki lima yang 


\section{Saran}

\begin{abstract}
berdagang malam dan menberikan sanksi kepada pedagang yang malas membayar uang kebersihan.

e. Pemerintah harus mengadakan sosialisasi program kebersihan secara rutin dan mendata pedagang yang hadir dalam sosialisasi tersebut agar menunbuhkan kesadaran terhadap pedagang kaki lima dalam pengeloaan kebersihan lingkungan
\end{abstract}

Berdasarkan kesimpulan telah di kemukakan di atas, maka selanjutnya penulis menemukan saran - saran sebagai berikut :

1. Pemerintah Kota Solok hendaknya dapat memotivasi pedagang kaki lima dalam pengeloaan kebersihan lingkungan melalui kegiatan penyuluhan kebersihan dan sosialisasi program kebersihan.

2. Melihat bentuk dan tingkat partisipasi pedagang kaki lima dalam pembayaran uang retribusi kebersihan tergolong rendah, hendaknya pemerintah Kota Solok melalui pengelola pedang kaki lima/pedagang malam menindak tegas oknum yang malas membayar uang retribusi kebersihan.

3. Dalam pengelolaan kebersihan lingkungan di lokasi tempat berjualan pedagang kaki lima hendaknya diawasi secara berkala oleh pemerintah Kota Solok atau melalui pengelola pedagang kaki lima /pedagang malam.
DAFTAR PUSTAKA

Budiharjo, Eko dan Hubuyo, Sudianti, Harjo. 1999. Kota Berwawasan Lingkungan. Bandung : Penerbit Alumni.

Efrida, Ade. 2012. Pengelolaan Kebersihan Lingkungan Pasar di Kenagarian Aur Kunng Kabupaten Pasaman Barat. Skripsi. Padang : STKIP PGRI

Jaswita, Desi. 2006. Perilaku Pedagang dan D:inas Pengelolaan Pasar Dalam Menjaga Kebersihan. Lingkungan Di Pasar Raya Solok. Skripsi. Padang : Fis UNP.

Nurmadi, A., 1999. Manajemen Perkotaan. Yogyakarta: Lingkaran Bangsa.

Karafir, Yan Picter. 1997. Pemupukan Modal Pedagang Kaki Lima. Jakarta : Penelitian Fisip UI.

Peraturan Daerah Kota Solok Nomor 13 Tahun 2012 tentang Pengelolaan Kebersihan di Kota Solok.

Peraturan Daerah Kotamadya Tingkat II Solok Nomor 5 Tahun 2017 tentang Penataan dan penberdayaan Padagang Kaki Lima

Ramli, R. 1991. Sektor Informal Di Perkotaan, Pedagang Kaki Lima Indonesia. Jakarta: Indonesia Hill Company

Riatna, Soeganda. (1997). Motivasi, Partisipasi dan Pembangunan. Jakarta: UK Pers/.

Undang-Undang Nomor 23 Tahun 1999 tentang Lingkungan Hidup.

http://lenterapena.blogspot.com/2012/06/ panduan-penentuan skoringkriteria.html 